\title{
The Issue of Popular Education in Selected Socio-Cultural Journals of the Kingdom of Poland in the 1905-1918 Period ${ }^{1}$
}

\begin{abstract}
The issue of popular education in the Kingdom of Poland started to arise as early as the period 1858-1860. Analysing the socio-cultural journals of this period one can easily see numerous articles and correspondence calling for society to propagate popular education (establishment of libraries, educating school teachers, propagation of youth associations, education of women etc.). The editors of the analysed journals, as well as the authors writing on the subject, stated that if progress and well-being were to be introduced in the countryside the only way was through development of broad popular educational activity.
\end{abstract}

Keywords: popular education, popularization of education, educational work, sociocultural journals, the Kingdom of Poland.

\section{Problematyka oświaty ludu na łamach wybranych czasopism społeczno-kulturalnych Królestwa Polskiego w latach 1905-1918}

\begin{abstract}
Abstrakt
Problematyka oświaty ludu na terenach Królestwa Polskiego zaczęła się pojawiać już w latach 1858-1860. Analizując czasopisma społeczno-kulturalne tego okresu, można dostrzec, że pojawiały się na ich łamach artykuły i korespondencje nawołujące społeczeństwo do krzewienia oświaty ludu (zakładania bibliotek, kształcenia nauczycieli szkół ludowych, propagowania zrzeszania się młodzieży, edukacji kobiet itd.).

\footnotetext{
* Nicolaus Copernicus University in Toruń. Article Received: January 31, 2020; Accepted: May 25, 2020.

1 This publication was financed under the programme of the Ministry of Science and Higher Education under the name "Paths to Independent Poland" in 2018-2023 project number 01SPN 17002018 funding amount PLN 751222.
} 
Redaktorzy analizowanych pism, jak i autorzy piszący na ten temat wyrażali przekonanie, że chcąc wprowadzić postęp i pomyślność na wsi, można tego dokonać tylko jedynie przez rozwinięcie szerokiej działalności oświatowej wśród ludu.

Słowa kluczowe: oświata ludu, popularyzacja oświaty, praca oświatowa, czasopisma społeczno-kulturalne, Królestwo Polskie.

The issue of the education of the people in the Kingdom of Poland, according to Karol Poznański, began to be raised in the years 1858-1860. Already at that time, education was seen as a chance for the social emancipation of the peasantry, which should be, it was believed, preceded by a broad educational movement. It was thought that both village schools and periodicals "should popularize the ideas of cooperation, harmony and trust (...) to disseminate the idea of respect for tradition, the property of others and fulfilment of obligations assumed" (Poznański 1964: 70). The turn of the 19th and 20th centuries was a period of very intensive development of literature, in which practically all the communities of the Kingdom of Poland aspiring to an independent shaping of public opinion were involved: from the conservative landed gentry and clergy, to the circles of positivists (Przeciszewska 2015: 197). Analysing the socio-cultural magazines of this period, one can easily see that articles and correspondence calling for society to promote the education of the people appeared in their pages. Writers on this topic were convinced that progress and prosperity could only be introduced by developing extensive educational activity among the people.

This article attempts to present issues related to the education of the people in selected socio-cultural magazines of the Kingdom of Poland in 1905-1918. Among the periodicals taken into consideration ${ }^{2}$ were those which regularly discussed such questions as: the low level of people's education, issues of working on the people and education for the people, the revival of society through educational work on children and youths, establishing and maintaining libraries at common schools, organizing of interest groups, the situation of young people and their education, preparation of school teachers, the health education of the people, etc. In addition, an important topic that also appeared in these periodicals was national education. As is well known, national education appears and develops especially when a nation is deprived of its individuality and statehood, and at the same time strives for freedom and independence (Wołoszyn 1998: 154). In this connection,

\footnotetext{
2 The periodicals analysed included such titles as: "Sztandar" (political, social and economic weekly, non-partisan), "Wyzwolenie” (weekly press organ of the Polish People's Liberation Party (Polskiego Stronnictwa Ludowego Wyzwolenie), "Ogniwo" (biweekly for Polish youths, a magazine devoted to youth issues, organizational, informational, educational, cultural, scientific, sporting and educational), "Polemista" (social and literary magazine), "Wolne Słowo" (social, political, literary and scientific weekly), "Odrodzenie" (political, social and cultural weekly), "Dzwonek Częstochowski" (Catholic monthly), "Świat" (illustrated socio-cultural weekly devoted to social life, literature and art).
} 
the role of culture, education and the Catholic Church in the work of restoring national identity was written about at the time. Analysing the socio-cultural periodicals at the time indicated in the title of the article, it is clearly visible that the editors of certain cited magazines were closely concerned with the issues of education among the people, and therefore these titles were included in this analysis of the issue.

There was often lively discussion in the pages of these publications about the low level of education of the people. For example, an article published in "Sztandar" raised the issue of the low level of education of Polesian peasants. The author blamed this on poor educational provision, the lack of a sufficient number of schools and nurseries, as well as faulty teaching methods. He pointed to the problems of discontinued learning, low level of social awareness and lack of a need for continuous education and development (Wilczkowski 1906). Similar reservations were raised by the author of the text Do szkół (To schools) who wrote about the need for education, especially in the countryside, and particularly with independence in mind. The author noted a lack of independent, enlightened and wise people, to be future members of the Polish parliament. The Polish countryside was struggling with backwardness, the decline of agriculture, apathy and lethargy. That is why it was necessary to establish primary schools, send young people to train as teachers, and not resent the funds given for education, to give the next generation a chance for an education and a better future (Owidzki 1917). The dangers of a lack of education in the nation were pointed out. The efforts of their fellow countrymen in organizing teaching during the partitions were emphasized and appreciated. Deficiencies in the education system were also noticed, i.e. the lack of accessibility for all citizens. That is why universal and free teaching was proposed, which should be at the common cost of the whole society (Oświata... 1907).

In turn, an unfavourable tendency in lectures for the people was noticed by the author writing under the pseudonym Rolnik. He signalled the problem of partisanship, which appears in many talks and is fatal to their reception, especially among young people. He gave examples of such lectures, which were of a seemingly educational character, but also contained a message of agitation and propaganda (Rolnik 1907).

Work aimed at improving the level of education would be a chance for change, it was thought, as it is necessary in the fight for independence. Also on the pages of "Wyzwolenia" (Liberation) the issue of improving the nation in the field of education for an independent Poland was raised. Education is, in the author's opinion, the most effective weapon in the fight for rights. The sooner the level of education increases, the sooner Poland will be democratic and for the people, and the government will better fulfil its tasks. Polish governments should be created by the conscious and collective will of the nation. That is why we need to set up as 
many schools as possible, this is the most important task. The development of education, as the author noted, is also followed by the well-being of the inhabitants (Zadania szkoły... 1917).

A gradual decrease in the importance of universities in the process of giving direction to education was also signalled. Their role is, in the opinion of the writers, one of scientific research and the education, as they defined it, of "qualified professionals". Therefore, the genesis and goals of Universal University Lectures were discussed, and thus the need for a well-planned and conducted popularization of learning among the people. The need for a so-called intermediate form between higher education and the needs and capabilities of a simple people was noted. The author of this observation referred for this purpose to the experience of the English in this area (Domy ludowe... 1907).

Analysing the condition and requirements of education at the time, it was pointed out that people with steadfast character and democratic principles were needed. In the text Uświadamiajmy lud (Let us make the people aware), the author thought that the education of the people was especially neglected, and that secret teaching did not bring the right results. He believed that there was also a need for national education, whose task would be to restore national consciousness and understanding of the obligations arising from the position of the patriot. Therefore, in his opinion, in reviving Poland it was necessary to make the people aware, and this task should be entrusted to educational institutions and popular political parties (Kozikowski 1917a).

Some solutions to the problem of low education were proposed e.g. in the article entitled Ciemnota największy nasz wróg (Ignorance is our greatest enemy), in which attention was paid to the need to educate not only children and teenagers in Polish national schools, but also adults. Private lessons as well as organized courses for adult learners could help in this process. The author of the text, hiding under the pseudonym Ludowiec, also noted that young people often devote their time to fun, entertainment and pleasure, forgetting about learning. The author noticed an example of such practices in the parish of Stolec, in the Sieradz poviat. He encouraged youths and adults to organize themselves, as well as establishing libraries and reading the press (Ludowiec 1918). Libraries were recommended to be established and maintained especially at common schools. The more so that, as noted, the work that teachers put into education, without the tools of textbooks and libraries equipped with them, could be wasted. The issue of reading was similar. That is why society should financially support the functioning of these institutions (Biblioteki szkolne... 1907).

Another form of education of the people was proposed by the author (Bojarska 1917) of the article entitled Dowód mocy ludowej (Proof of people power), in which she drew attention to the functioning of agro-social courses organized by the 
agricultural circle of St. Staszica, for adults of both sexes ${ }^{3}$. She appreciated both the input of teachers who wanted to transfer as much knowledge as possible to their students, and the commitment of students who were ready to share the effects of their work with less educated colleagues. The author (ibidem) mentioned that the programme of the course, in addition to issues related to agriculture and breeding, nature, Polish, and arithmetic, included an extensive historical and social section, which is noteworthy. The circle members are therefore interested in historical, political and social content. Talks and readings were also popular. The listeners took part in the discussions, used the advice, and revealed their economic and organizational abilities. The author (ibidem) of the text also appreciated the great involvement of young people in this type of initiative. It should be supposed, she wrote hopefully, that the graduates of these courses will in the future form a group of serious educators and social activists, promoting social and national awareness in their area (ibidem: 1918).

The importance of schools and agricultural courses for the development of awareness and education among the people was written about with particular hope. These facilities prepared young people not only for social, but also political work. To strengthen this potential, conventions and additional courses were also organized to tie young people closer to education. In this context, the role of the magazine "Drużyna" (The team) in the work of connecting young people with school was also appreciated. It was noted that due to the suspension of this periodical, the activity of the "Mieczysławowiacy" (people of Mieczysławów) was worth noting, as they encouraged social work by organizing, for example, the Association of Friends (Przykład do... 1917).

The author (Kozikowski 1917b) of the less optimistic article entitled Walka $z$ ciemnota, (Fighting ignorance), pointed to the low popularity of courses designed for adults who are unable to read and write. In his opinion, this is because the motivation among the common folk is too weak. Understandably, the Russian government did not care about education. If education were at a higher level, the author wrote, Poles would not be subject to such unlawfulness and oppression by the Russian authorities. In addition, the lack of its own government and education system meant that Poland did not develop in educational, economic and social terms. The author also noted that at every step the Russians express their dislike of Poles. It is even more important to establish schools and courses that would help in the fight against illiteracy.

In these magazines, small, but important, bottom-up educational initiatives were also appreciated. The author appearing under the pseudonym Czytelnik presented the circumstances of the creation of a new school - the Tadeusz Kościuszko People's School in the village of Nieskórzu near Ostrów (Łomża

\footnotetext{
3 The author wrote about courses and educational work initiated by the St. Staszica Society of Agricultural Associations in Pułtusk.
} 
Province). The inhabitants of this town rebuilt a building in which a primary school could be established, at their own expense, thus wishing to contribute not only to the reconstruction of Polish education, but also the entire state. In addition, it was noted with joy that a Youth Association (Czytelnik 1917) was also founded in this school.

The revival of society through educational work on children and youths was also an important problem discussed in such magazines as "Wyzwolenie" and "Sztandar". The writers noted that young people are the future of a nation on the verge of independence. The size of the nation and its strength depend on the love for its own homeland, as well as on diligent and skilful action. That is why, in the opinion of the writers, the Polish youth should be the foundation of the nation's strength and durability. The future of Poland will be what the young generation will do. This is a great and responsible task, so you need to prepare yourself for it. The authors (Smoła 1917; Czytelnik 1917; Wasz kolega Sokołowiak z pod Łomży 1917) raising these issues looked particularly at the rural youth, in which, on the one hand they saw fighting spirit and strength, but on the other hand, many temptations prevented them from acting bravely and steadfastly for the good of the nation (Smoła 1917). Therefore, they appealed to young people who do not take the trouble to work and fight. It was believed that young people could no longer remain idle. Particular attention was paid to the patriotic and civic attitude important in educating the younger generation, without which it is difficult to imagine the reconstruction of the state (Wasz kolega Sokołowiak z pod Łomży 1917). The chance for a revival of society through educational work on children and youths was seen in changing the educational system in all spheres (e.g. infrastructure and education policy). Examples were given of the life of small, rural schools and the problems faced, e.g. by teachers (confined space, lack of teaching aids, etc.). It was also suggested that there were not enough people prepared for teaching work (E. B. 1907).

The need to establish associations of rural youths was also noticed. The publications promoted and presented step by step guides to setting up such groups (starting with the selection of an organizational committee, a president; establishing the rules according to which they should operate and defining goals of action, etc.). Attention was drawn to the need to create sections in such associations, especially educational ones, whose main goal would be to spread education among the members of the group, arrange lectures, organize talks on current topics, etc. In turn, health and physical development sections would be responsible for promoting the passion for scouting, and promoting sports and games. An important role of this type of section, as we read in the article, would also be to organize lectures on health (Ołdakowski 1917).

Another problem in connection with the education of young people was indicated by the author (Karczewska 1917) of the article entitled Na nowy rok szkolny (For the new school year). She claimed, like many of her contemporaries, 
that the future of the country depends on the education of children and young people. However, parents often want not education but wealth for their children, which she regretted. She criticized, therefore, the disadvantage caused by parents sending their children to school not from the beginning of the school year, but with a long delay resulting from the need to complete work in the fields. Teachers must deal with this situation, usually in autumn and spring. The author also added that no teacher is able to achieve satisfactory results in such conditions. In addition, she pointed out that the total time of schooling in such cases was only 4-5 months. Parents sending their children to school in such an irregular way not only ruin their own well-being and happiness, but also the future success of the entire nation (Karczewska 1917).

The need to educate teachers was also discussed in socio-cultural magazines of the Kingdom of Poland. For example, the author (Perej 1907) of the article entitled Seminarium dla nauczycielek ludowych (A seminar for teachers of the common folk) discussed the programme of such a seminar created in Warsaw in 1907, initiated by teachers of Warsaw schools, aware of the need to create courses for folk teachers as soon as possible. This institution was to raise the level of education and civic awareness especially among those teachers who were insufficiently prepared to perform their duties (Perej 1907; Instrukcje dla... 1905).

A little space in the surveyed socio-cultural periodicals was devoted to the problem of educating women and preparing them for life in society. For example, the author, who signed herself as Siostra z nad Nidy, pointed to the importance of the role of the mother in preparing the younger generation. Therefore, in her opinion, one should look at the education of women who raise children, especially in the countryside. In addition, the text reviewed the state of education for rural girls. It stated that there were too few educational institutions, and that they should be located in every commune. She also noted that courses, conventions (she pointed to the Congress of the Landladies) and peasant associations could help in educating women. She added that especially during the Congress of the Landladies important issues were discussed, such as, raising children to be good citizens and patriots; what a woman can do on commune councils in matters of education, health and charity; and how to run a farm (Sister z nad Nidy 1917).

As previously mentioned, a little more space was devoted to the issue of national education. This question was considered together with the role of education, culture and the Catholic Church in the work of rebuilding national identity. Attention was paid to the need for reviving cultural life and mental action. The importance of Catholicism in maintaining tradition was emphasized. The creation of centres of Polish culture and education that could gather Poles and respond to cultural and educational needs was encouraged (Huzarski 1913). It was suggested that care for the purity of the mother tongue was also necessary. For example, Jur Kamieński (1910) devoted attention to this issue in the journal "Odrodzenie". He expressed the opinion that the mother tongue should be 
cherished by, and important for, everyone. As he wrote: "Language reflects the spirit of culture and the degree of national mentality" (Kamieński 1910). That is why he was sad to say that there were no schools where the language was treated with special care. He criticized the frequent borrowing from foreign languages, while neglecting the folk dialects, which are, after all, of cultural value.

Other authors (e.g. Mańkowski 1907) also noticed the problem of somehow retaining the culture while developing, and the danger of being influenced by Western culture. According to them, these phenomena result from the current breakdown, and the lack of uniform development and a national school system. Different views on the role of culture are the result of varied learning opportunities, trips abroad, and influences from foreign schools. The question of denationalization is also dangerous in this context. That is why it is necessary to cultivate Polish culture and skilfully combine foreign influences with what is native (ibidem).

The need for national education was also emphasized. For example, the creation of Polish Educational Societies (Macierzy Szkolnej w Królestwie Polskim) was highlighted. Therefore, there was encouragement to set up schools, and organize courses and lectures whose task would be to spread elementary culture and decency among the people (Głos z Podola... 1907). Analysing these voices in selected magazines, it can be stated that the activity of the Educational Societies was appreciated and their initiatives were described. In turn, "Wolne Słowo" reported the regrettable suspension of their work (Belmont 1907).

No less important was the health education of the people. Interesting materials regarding this problem are provided, for example, by the "Dzwonek Częstochowski", in which, since 1906, social and economic topics had been raised ${ }^{4}$. Articles devoted to the dangerous effects of drunkenness could be found there. Texts in which the authors warned against alcohol abuse should also be mentioned (Do czego... 1907; Wódka szkodzi... 1905). It was argued that alcohol has destructive effects not only on those who abuse it, but also on the functioning of the family and society (Niektóre przyczyny... 1905). In addition, on the pages of this magazine one could find educational articles on various diseases and emergency procedures (Gębarski 1907a).

The issue of health education was also taken up in the pages of "Wyzwolenia". In the article entitled Parę słów w sprawie zdrowia ludu (A few words about the health of the people), the author (Nasiłowski 1917) pointed out that every enlightened person should not only follow hygiene recommendations, but also educate others about how to apply these recommendations in everyday life. He also noted that the country should pay more attention to the health of the people and issue relevant laws affecting the condition of the entire nation. In order to become better acquainted with hygiene recommendations, the author also

\footnotetext{
4 "Dzwonek Częstochowski" was a Polish illustrated Catholic monthly published in Częstochowa, 1901-1915.
} 
suggested reading books, e.g. those published by the Galician Education Society (Nasiłowski 1917). Similarly, the level of hygiene was discussed in a short text in "'Wolne Słowo" (Wymowa cyfr... 1913).

To sum up the above considerations, it should be said that the education of the people was an important issue, especially in the period before independence. The most important problems were signalled in the periodicals analysed, i.e. to raise the level of education of the lowest levels of society, to establish various types of schools, and to popularize the education of young people. These issues were associated with national education, emphasizing the importance of culture, tradition and language. Of course, these problems appeared less frequently in social and cultural periodicals than, for example, in educational magazines of that period. Nevertheless, an analysis of this type of literature allows us to see which issues enjoyed the greatest attention, and which were considered the most pressing with a view to a free homeland.

\section{References}

Belmont L. (1907) Zamknięta Macierz, "Wolne Słowo", 4: 1-3.

Biblioteki szkolne, (1907), "Sztandar", 19: 5-6.

Biernacka M. (1984) Oświata w rozwoju kulturowym polskiej wsi, Wrocław, Wydawnictwo Polskiej Akademii Nauk.

Bojarska S. (1917) Dowód mocy ludowej, “Wyzwolenie”, 18: 191-192.

Bojarska S. (1918) Sami sobie budujq lepsza przyszłość (Wieści z ziemi pułtuskiej), "Wyzwolenie", 1: 4-5.

Czytelnik W.A. (1917) Szkoła Ludowa im. Tadeusza Kościuszki, “Wyzwolenie”, 46: 442.

Do czego pijaństwo doprowadzi. Odstraszające przykłady, (1907), "Dzwonek Częstochowski", 6 (67): 86-90.

Domy ludowe i uniwersytety powszechne w Anglii, (1907), “Sztandar", 20: 15-16.

E. B. (1907) Listy z nad Prosny (Opieka nad dziatwa), "Sztandar", 16: 7-8.

Gębarski S. (1907a) O otruciach, “Dzwonek Częstochowski”, 3 (64): 100-104.

Gębarski S. (1907b) Pomoc doraźna w przypadkach krwotoku, "Dzwonek Częstochowski", 2 (63): 90-92. 
Głos z Podola (1907) Przez ochronkę do szkoły, przez ochroniarki do nauczycielek, "Sztandar", 17: 7-8.

Huzarski J. (1913) O czem się dziś nie mówi: Niewyzyskane siły, “Polemista”, 12: 15-16.

Instrukcje dla nauczycieli szkół ludowych (1905), “Ogniwo”, 35: 920.

Kamieński J. (1910) Nasz język, “Odrodzenie”, 25: 377-379.

Karczewska W. (1917) Na nowy rok szkolny, “Wyzwolenie”, 37: 371-372.

Kmiecik Z. (1976) Prasa polska w latach 1864-1918, Warszawa, Państwowe Wydawnictwo Naukowe.

Kozikowski E. (1917a) Uświadamiajmy lud, “Wyzwolenie”, 9: 102.

Kozikowski E. (1917b) Walka z ciemnota, "Wyzwolenie”, 6: 66-67.

Ludowiec (1918) Ciemnota największy nasz wróg, "Wyzwolenie”, 6: 56-57.

Lutosławski W. (1910) Wpisy szkolne, "Świat", 6: 3-5.

Mańkowski J. (1907) Strzeżmy własnej kultury, “Sztandar”, 21: 1-2.

Nasiłowski A. (1917) Parę słów w sprawie zdrowia ludu, “Wyzwolenie”, 43: 416.

Niektóre przyczyny pijaństwa (1905), “Dzwonek Częstochowski”, 6 (48): 122-124.

Perej St. (1907) Seminarium dla nauczycielek ludowych, "Sztandar", 7: 6-7.

Ołdakowski M. (1917) W sprawie Kół młodzieży wiejskiej, “Wyzwolenie”, 51: 481.

Oświata. (Co się w niej robi a jeszcze robić trzeba) (1907), "Sztandar”, 19: 3.

Owidzki L. (1917) Do szkół, “Wyzwolenie”, 24: 251.

Poznański K. (1964) Opinia publiczna Królestwa Polskiego wobec sprawy oświaty ludu w 1861 roku, "Rozprawy z Dziejów Oświaty", 7: 70.

Przeciszewska M. M. (2015) Tygodnik ilustrowany "Oświata" jako narzędzie formowania "cesarskiego chłopa" w Królestwie Polskim w latach 1900-1905, "Rocznik Biblioteki Narodowej", XLVI: 197-220.

Przykład do naśladowania (1907) “Wyzwolenie”, 44: 424-425. 
Rolnik (1907) Partyjność a oświata, “Sztandar”, 26: 3-4.

Siostra z nad Nidy (1917) Pomyśleć o tym, “Wyzwolenie”, 22: 231-232.

Smoła J. (1917) Do was druhowie i druhnie, "Wyzwolenie”, 49: 465-466.

Wasz kolega Sokołowiak z pod Łomży (1917) Sokołowiak do sokołowiaków i młodzieży ziemi łomżyńskiej, "Wyzwolenie", 28: 290-291.

Wilczkowski K. (1906) Na Kresach (List z Polesia i Wołynia), “Sztandar”, 14: 4.

Wołoszyn S. (1998) Nauki o wychowaniu w Polsce w XX wieku. Próba syntetycznego zarysu na tle powszechnym, Kielce, Dom Wydawniczy Strzelec.

Wódka szkodzi zdrowiu i przyśpiesza śmierć, (1905), "Dzwonek Częstochowski”, 3 (45): 105-106.

Wymowa cyfr (1913), “Wolne Słowo”, 191: 20.

Zadania szkoły ludowej (1917), “Wyzwolenie”, 19: 199-200. 